\title{
Biochemical estimation of some metabolites and enzymes from biodiesel plantPongamiapinnata $(\mathbf{L}$.
}

\author{
Richa Choudhary ${ }^{1}$ and Sanjay Kumar ${ }^{2}$ \\ 1. Department of Botany, M. S. J. Govt. P. G. College, Bharatpur,Rajasthan University, India \\ 2. Department of Botany, M. S. J. Govt. P. G. College, Bharatpur,Rajasthan University, India
}

\begin{abstract}
The present study was conducted for estimation of metabolites and enzymes of Pongamiapinnata abiodiesel plant of great economic importance.The hypertrophy and hyperplasia of plant tissues result in theformation of galls in some plants.Pongamiapinnata has Leaves galls induced by Aceriapongamiae.Biochemical analysis revealed hyperauxiny and hypoindole 3 acetic acid oxidase activity in the gall tissues.

Keywords:Pongamiapinnata, biodieasel, gall,invertase, auxin, chlorophyll, caroteinoid, enzymes
\end{abstract}

\section{Introduction}

In order to address the shortages of feedstock for the production of biodiesel, new non-edible oil sources need to be exploited (Lin et al., 2011; Mustafa, 2011).Over hundred plant species are known to produce fatty acid oil. Among the oil bearing tree, Pongamiapinnata (family Fabaceae) also known as "Karanja"in India, appears to be a potential source of biodiesel (Sharma and Singh, 2008; Naiket al., 2008; Nabiet al., 2009). It is medium sized glabrous evergreen tree with short bole attaining height of around 18-20 meter and its habitat is in the littoral region of south east Asia, Australia and widely distributed in India, Pakistan, Bangladesh, Philippine and Australia. This multipurpose tree has lot of industrial and medicinal applications. It is the one of the most extensively chemically investigated plant.Many gallers destroy plant parts with obvious links to host fitness, and compete with plant organs for nutrients and photosynthate and reduce it's economically importance.Aceriapongamiae(Acarina: Eriophyidae) that induce pouch galls on the leaves of Pongamiapinnata. A. pongamiaesynchronizes its development with the host phenology and it confirms the fact that life-history patterns of gall midges are closely linked to their host-plant phenology (Parnell, 1964; Tokuda and Yukawa, 2007).

\section{Materials And Methods}

Normal and galled Pongamiapinnataleaves of equal size were collected from KeolaDeoNational park, Bharatpur,Rajasthan and their biochemical study was done. The biochemical parameters were studied in normal and gall leaf at different ages (10days, 20days and old). The plant leaves (normal and galled) were separately washed with running water to remove dust and powdered with motor and pestle.

The quantitative estimation of primary metabolites was carried out using different protocols. The powdered plant leaves (normal and galled) and were used for estimation of IAA oxidase and total auxinand free auxincontents were estimated by the method of Avery et al.(1945),invertase activity (Harris and Jaffcoat,1974), chlorophylls (Arnon,1949), carotenoid (Mahadevan and Sridhar, 1982)and lipid(Jayaraman, 1981) respectively.

The present work incorporates the biochemical estimation of some metabolites and enzymes of normal and galled leaves of Pongamiapinnataat different ages.

\section{Results And Discussion}

The results are presented in table 1 and Fig. - 1 to 7.

Plants are rich sources of primary metabolites which are useful in flavoring, fragrances, insecticides, sweeteners and natural dyes (Kaufman et al., 1999). Primary metabolites analysis is necessary for knowing the nutritional potential of plants and them also from the precursors for the synthesis of secondary metabolites (Vijayvergia and Kumar, 2007).

Higher amount of free auxin contentsand IAA oxidase was found in the gall tissue as compared to normal tissue.High levels of auxin will cause cell expansion (hypertrophy) and cell division (hyperplasia) in many plants (Sachs, 1961; Jablonski and Skoog, 1954; Nitsch, 1968). In old gall the number of infected larva is rises so IAA contents observed is more amount. Indole-3-acetic acid (IAA), the main auxin in higher plants, has profound effects on plant growth and development. Both plants and some plant pathogens can produce IAA to modulate plant growth (Zhao, 2010). Although most investigations report hyperauxiny in galls, in a few cases reduced auxin levels has been reported (Ramani and Kant, 1989). The amount of total auxinwas reduced may be due to destruction by enzymes secreted by the parasite/insect or by enzyme of the infected plant or reduced concentration and conversion of auxin precursors (Gupta, 2011). 
Invertase activity was recorded to be more in gall tissue as compared to normal tissues. Invertases are key metabolic enzymes that involved in various aspects of the plant life cycle and alone or in combination with plant hormones, can regulate many aspect of the growth and development of plants.

Highest amount of total chlorophyll and carotenoid was recorded in normal tissue as compared to gall tissues (10days, 20days and old). Chlorophyll is the most indispensable class of primary compounds as they are the only substances that capture sunlight and make it available to plant system for its cultivation on photosynthesis (Murray et al., 1986). The decrease in the photosynthetic pigments may be due to the inhibition of pigment biosynthesis which may results from the alteration in mineral nutrition or lack of assimilates which drain towards the insect or to the effect of reactive oxygen species on these pigments (Stacey and Keen, 1996). Degradation of chlorophylls compounds in aphid induced galls has earlier been reported by Miles (1968) and Purohit (1979).There are over 600 known carotenoids; they are split into two classes, xanthophylls (which contain oxygen) and carotenes (which are purely hydrocarbons, and contain no oxygen). Carotenoids in general absorb blue light. They serve two key roles in plants and algae: they absorb light energy for use in photosynthesis, and they protect chlorophyll from photodamage (Armstrong and Hearst, 1996).

Lipid was recorded to be more in normal tissue as compered to gall tissues (10 days, 20 days and old).Plants protect themselves from herb ivory by the formation of a layer of lipid material called thick cuticle (a waxy outer layer) which reduce water loss and work as a defense against some insects (Taiz and Zeiger, 1998).Lipid a diverse group of primary metabolites, include reserve plant material such as fats, essential oils, waxes terpnoids and oleoresin. Plant lipid have developed products that work with diverse requirements, be it culinary, medicinal or cosmetic (Yadav and Tyagi, 2006).

The majority of lipids in biological systems function either as a source of stored metabolic energy or as structural matrices and permeability barriers in biological membranes. Very small amounts of special lipids act as both intracellular messengers and extracellular messengers such as hormones and pheromones.

Table 1. Biochemical Metabolites in normal and galled leaf tissues during cecidogenesis (Mean value of 3 replicates)

\begin{tabular}{|l|c|c|c|c|c|c|c|}
\hline $\begin{array}{l}\text { Ts } \\
\text { Tissue }\end{array}$ & IAA oxidase & $\begin{array}{l}\text { Invertase } \\
\text { activity }\end{array}$ & $\begin{array}{l}\text { Total auxin } \\
\text { content }\end{array}$ & $\begin{array}{l}\text { Free auxin } \\
\text { content }\end{array}$ & $\begin{array}{l}\text { Total } \\
\text { chlorophyll }\end{array}$ & Carotenoid & Lipid \\
\hline Normal & 0.68 & 11.6 & 4.74 & .05 & 1.034 & 4.47 & 2.40 \\
\hline 10days leaf gall & 1.48 & 28.32 & 2.4 & .234 & 0.584 & 2.41 & 0.90 \\
\hline 20days leaf gall & 0.82 & 22.46 & 3.7 & .315 & 0.507 & 2.46 & 1.20 \\
\hline Old leaf gall & 2.09 & 21.48 & 2.5 & .117 & 0.59 & 2.334 & 1.60 \\
\hline
\end{tabular}

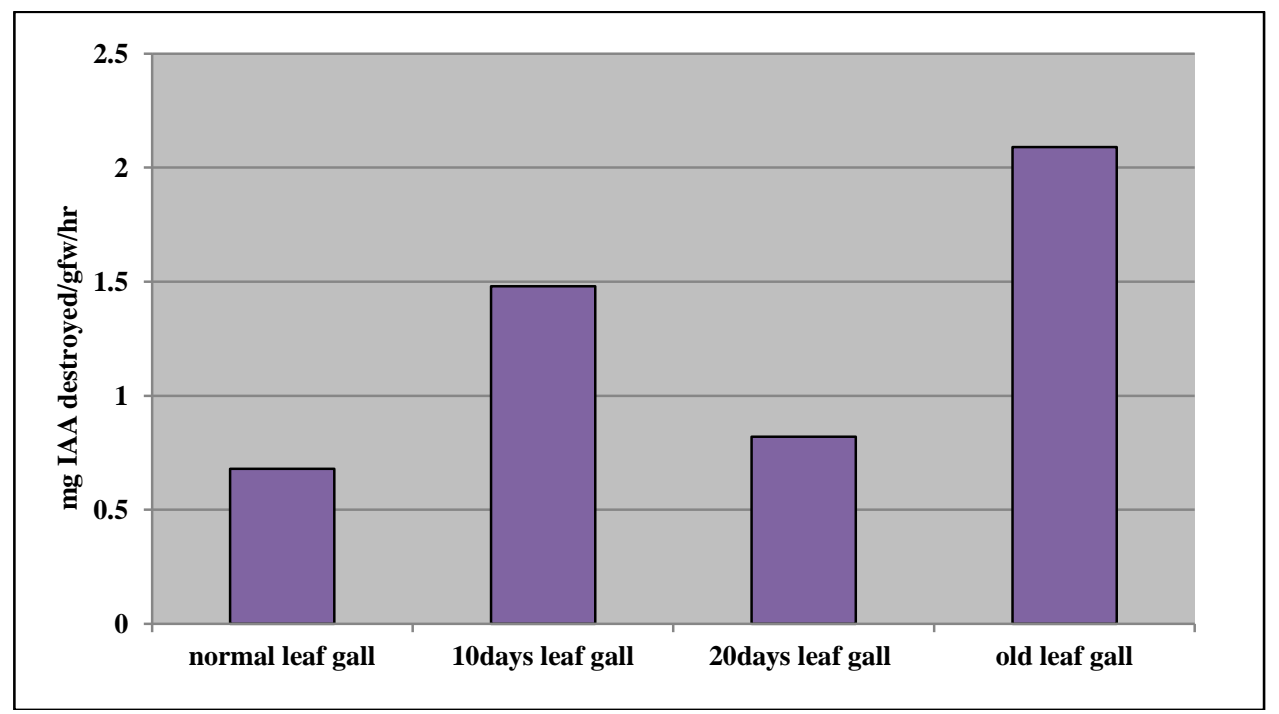

Fig: 1 showing amount of IAA oxidase in normal and gall (10days, 20days and old) leaves. 


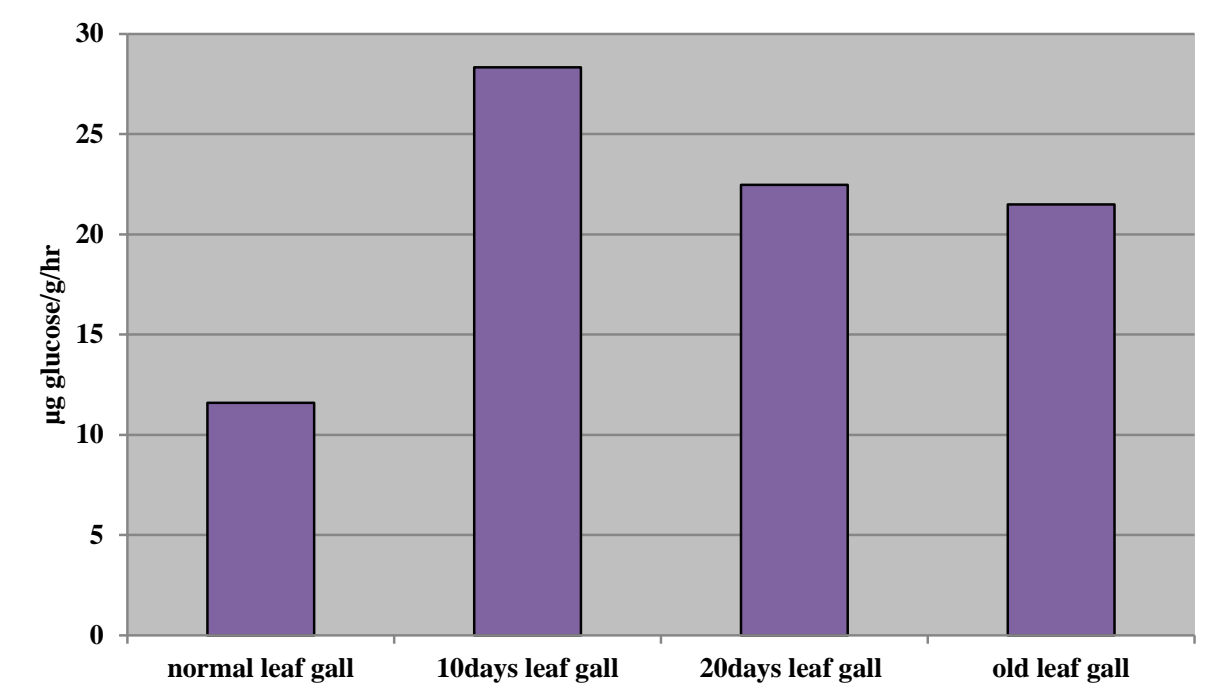

Fig: 2 showing amount of Invertase activity in normal and gall (10days, 20days and old) leaves.

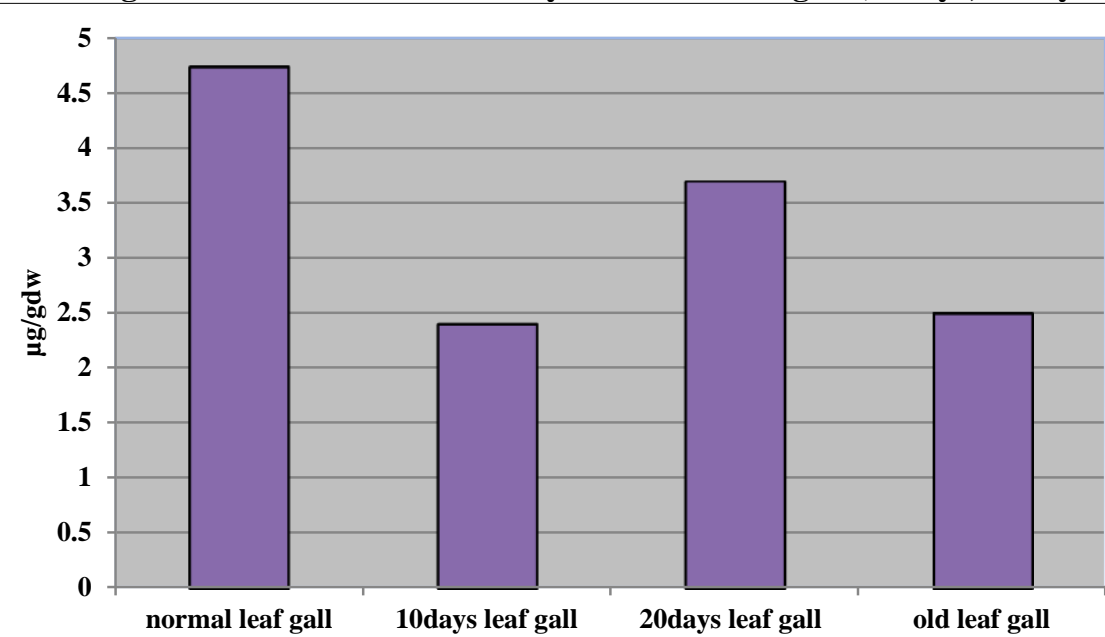

Fig: 3 showing amount of total auxin content in normal and gall (10days, 20days and old) leaves.

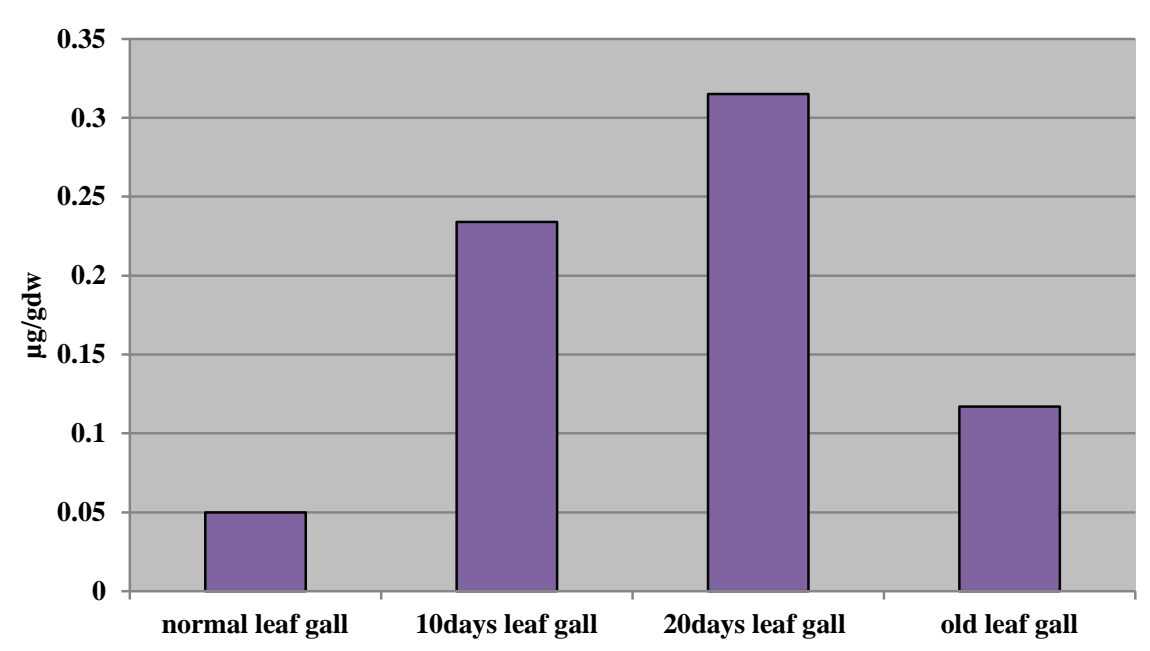

Fig: 4 showing amount of free auxin content in normal and gall (10days, 20days and old) leaves. 


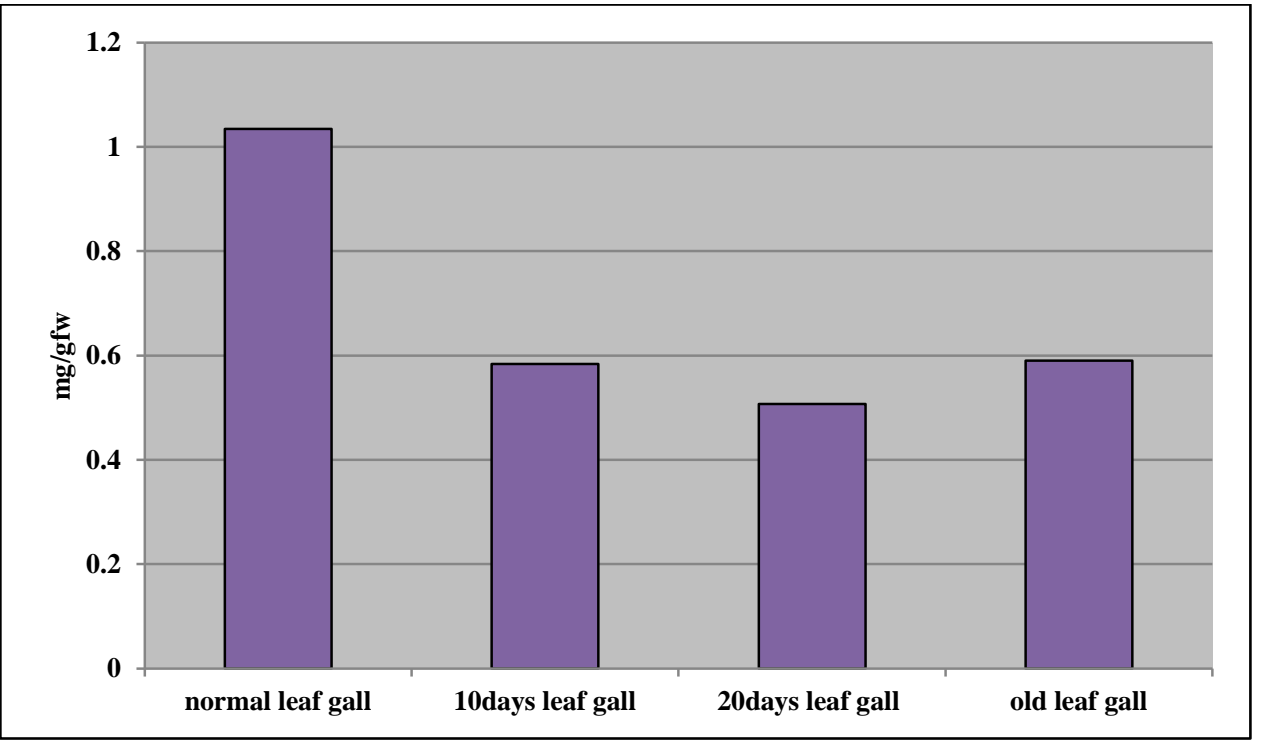

Fig: 5 showing amount of Total chlorophyll in normal and gall (10days, 20days and old) leaves.

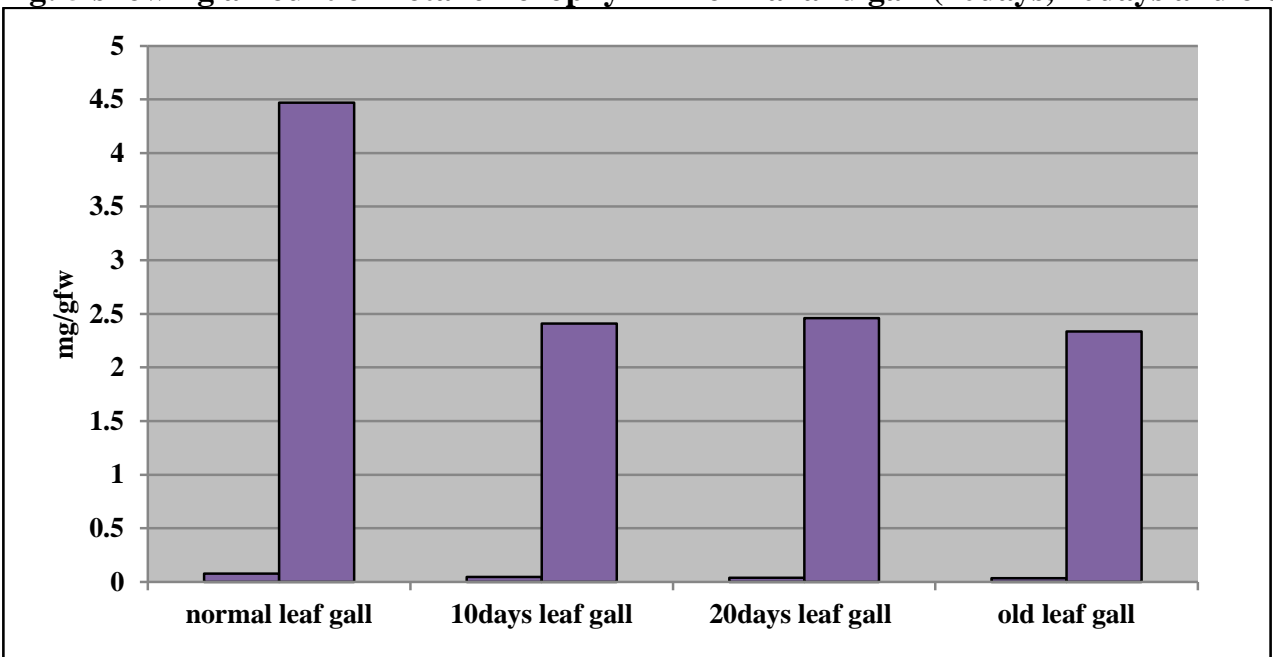

Fig: 6 showing amount of carotenoid in normal and gall (10days, 20days and old) leaves.

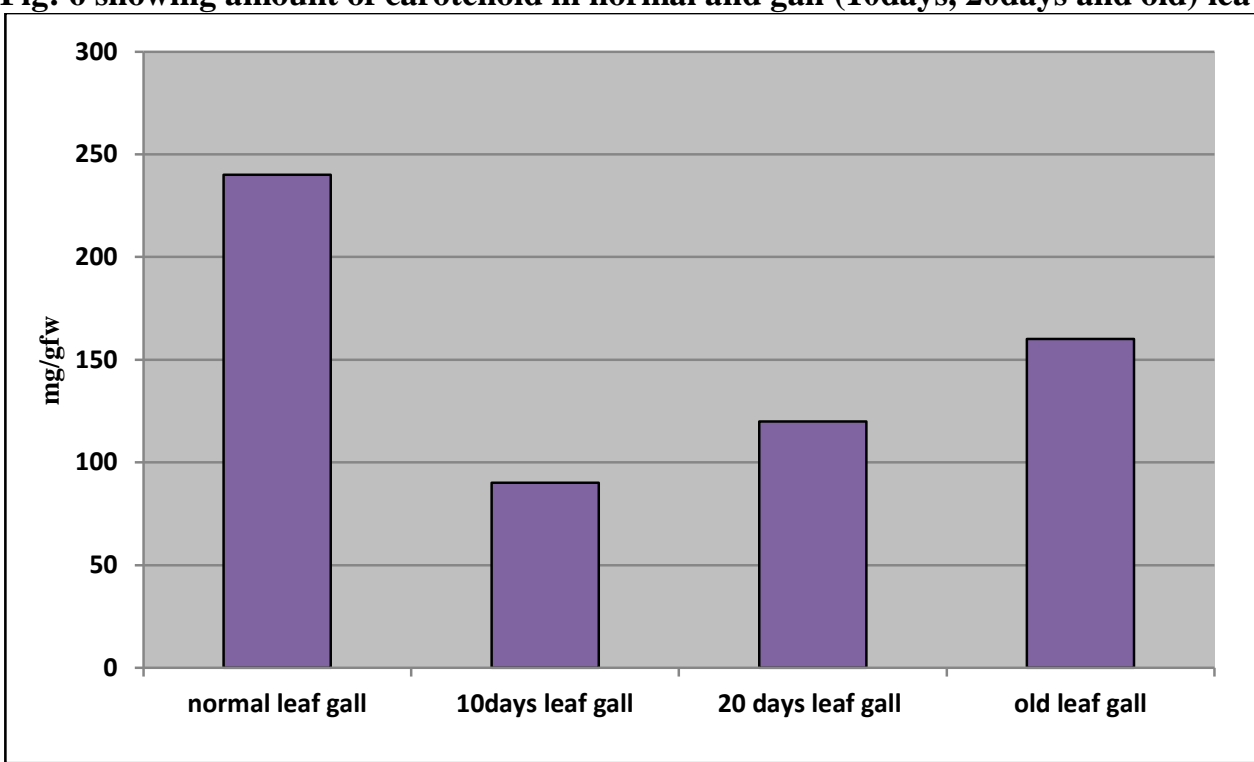

Fig: 7 showing amount of lipid in normal and gall (10days, 20days and old) leaves. 


\section{Conclusion}

The present study revealed the nature of metabolites and enzymes that are depleted from leaf tissue during gall formation as a consequence of the invasion of the parasite. The reduction in the metabolites and enzymes mentioned in the results in the galls may be a case of deficiency thus increasing the susceptibility of the plant to insect parasite.

\section{Acknowledgement}

Financial assistance granted by UGC as major research project to carry out this research work is great fullyacknowledged.

\section{Reference}

[1] A. Mahadevan and R. Sridhar, Methods in physiological plant pathology (Sivakasi Publication, Madras, 1982) pp. 79-80.

[2] A.P. Murray,C.F. Gibbs,A.R. Longmore,Determination of chlorophyll in marine waters: Inter comparison of a rapid HPLC method with full HPLC, Spectrophotometric and fluorometric methods,Mari. Chem, 19, 1986, 211-227.

[3] B. Mustafa,Potential alternatives to edible oils for biodiesel production-A review of current work,Energ. Convers. Manage. 52 (2), 2011, 1479-1492.

[4] D.I. Arnon,Copper enzymes in isolated chloroplast polyphenol oxidase in beta vulgaris, plant physiol., 24, 1949, 1-15.

[5] G.A. Armstrong, J.E. Hearst, Carotenoids 2: Genetics and molecular biology of carotenoid pigment biosynthesis,Faseb J.,10 (2), 1996. 228-37. PMID 8641556.

[6] G. P. Harris and B. Jaffcoat1974,Ann. Bot. 38, 77-83.

[7] G. Stacey and N. Keen. 1996. Plant-Microbe Interactions. Volume 2. Chapman and Hall Publ., New York-London.

[8] J. Jayaraman, Laboratory manual in biochemistry, Wilsey Eastern Limited: New Delhi, 1981, 96-97.

[9] J.P. Gupta,Auxin and IAA oxidase activity related to the leaves gall formation in some forest trees,Science Research Reporter, 1(2),2011,108- 111 .

[10] J.P. Nitsch1968. Pp. 536-580.In Biochemistry and Physiology of plant growth Substances (Edited by F.Wightman and G. Setterfield) 1868.Runge Press, Ltd. Ottawa, Canada. 1642p.

[11] J.R. Jablonski and F. Skoog,Pysiol.Plant., 7, 1954,16-24.

[12] J.R. Parnell, Investigation on the biology and larval morphology of the insects associated with the galls of AsphondyliasarothamniH. Loew (Diptera:Cecidomyiidae) on broom (Sarothamniscoparius(L.) Wimmer.). TransR EntomolSocLond, 116,1964, 255-273.

[13] L. Lin, Z.Cunshan,S.Vittayapadung, S. Xiangqian, D. Mingdong, Opportunities and challenges for biodiesel fuel, Appl. Energ., 88 (4), 2011, 1020-1031.

[14] L. Taiz, and E. Zeiger, Plant Physiology (Sinauer Associates Inc., Publishers. Sunderland,Massachetts, 1998).

[15] M.N. Nabi, M.N.Hoque andM.S. Akhter, Karanja (PongamiaPinnata) biodiesel production in Bangladesh, characterization of karanja biodiesel and its effect on diesel emissions, Fuel Process. Technol. 90 (9), 2009, 1080-1086.

[16] M. Naik, L.C. Meher, S.N. Naik, L.M. Das, Production of biodiesel from high free fatty acid Karanja (Pongamiapinnata) oil, Biomass Bioenerg., 32 (4), 2008, 354-357.

[17] M.R. Avery, J. Berger and R.O. White, .Am.J.Bot. 32, 1945, 188-191.

[18] M. Tokuda and J. Yukawa, Biogeography and evolution of gall midges (Diptera: Cecidomyiidae) inhabiting broad-leaved evergreen forests in Oriental and eastern Paraearctic regions. Oriental Insects, 41, 2007, 121-139.

[19] P.B. Kaufman, J.A. Dake, H. Briclmam,S. Cseke ,S. Warber, Natural products from plants(CRC Press. Boca Ratton, F.L.,1999).

[20] P. R. Yadav and R. Tyagi, Lipid Biotechnology.(Discovery publishing house-New Delhi, 2006).

[21] P.W. Miles, Insect secretions in plants. Ann. Rev. Phytopath. 6,1968,136-164.

[22] R. Vijayvergia and J. Kumar, 2007. Asian J.Exp. Sci. 21(1): 123-128.

[23] Sachs 1961. Pp. 42-51.In Paper on Plant Growth and Development.1967. (Edited by W.M. Laetsch and R.C.Cleland).Little, Brown and Co., Boston.479p.

[24] S.D. Purohit, K.G. Ramawat, andH.C. Arya, Phenolics, peroxidase and phenolase as related to gall formation in some arid zone plants, Curro Sci. 148,1979, 714-716.

[25] V. Ramani, U. Kant and M.A. Quereshi, Auxin profile of gall and normal tissues of prosopis cineraria(Linn.) Druce induced by Lobopteromyiaprosopidismaniin vitro and in-vivo, Proc. Indian Acad. Sci. (plant sci.) Vol. 99, 1989, $385-389$.

[26] Y.C Sharma and B. Singh, Development of biodiesel from karanja, a tree found in rural India, Fuel 87 (8-9), 2008, 1740-1742.

[27] Y. Zhao,Annual Review of Plant Biology., 61,2010,49-64. 